\title{
Position Of The Deed Of Will Made By Notary In Dispute Between The Heirs (Case Study Of Religion Court Decision No. 0427/Pdt.G/2014/PA.bla)
}

\begin{abstract}
Nurul Kusumawati ${ }^{1}$ and Akhmad Khisni ${ }^{2}$
Abstract. An inheritor can make a deed of will before a Notary, so that in a dispute occur later on between the heirs, the deed of will can be used as a basis for deciding the dispute between parties. Notaries who have the authority to make a deed of will have the obligation to serve the community in making a deed of will in the form of an authentic deed as stipulated in Article 15 paragraph (1) of Law Number 2 year 2014 concerning Amendments to Law Number 30 on the Position of Notary, which reads " The Notary has the authority to make authentic deeds regarding all deeds, agreements, and stipulations required by legislation and/or desired by the interested parties to be stated in an authentic deed, to guarantee certainty of the date of making the deed, to store the deed, give grosse, copy and quote of deed. All of those matters can be done by the notary as long as the deed is not also assigned or excluded to other officials or other people determined by law". So it is expected that the will certificate in the form of an authentic deed made by a notary based on the will of the inheritor can provide a solution that can be used as a basis in deciding a case of dispute between heirs. Legally, the heirs have secured the right as an heir, in accordance with Article 874 of the Civil Code. Related to the dispute between the heirs caused by the will deed made by the Notary, the Court take responsibility to overcome the dispute, so that all parties can get legal certainty.

Keywords: Testament Deed, Authority of Notary, Dispute of Heirs
\end{abstract}

\section{Introduction}

Legacy is one of the crucial things concerning the relationship among the heirs. Disputes require legal certainty which becomes guidelines and references in resolving the problem. Disputes arise between heirs, especially in the case of inheritance distribution, the heirs have different in interests and perceptions in controlling the inheritance. Based on the provisions in Article 834 the Civil Code, it is formulated that "the beneficiary heir has the right to control the assets of the inheritor (boedel) based on his rights as the recipient of inheritance from the inheritor". ${ }^{3}$

Willing is a legal act which contains a statement from an heir about what he wants after he dies. The will is stated in an authentic deed which is often called a testament or will. Authentic deeds provide perfect evidentiary power for the parties, heirs and those who get the rights. The Will Deed is an authentic deed because its form has been determined in a statutory regulation, made by an authorized Public Officer, and carried out in the working area of the authorized Public Officer. The form is regulated in such a manner by the law, it is called the authentic deed. It consists of the head of deed, deed body, and end of deed ${ }^{4}$. The testament deed/will deed is made before a Notary and in the form of a deed. So that the will deed made is a form of proof that is perfect if there is a dispute in the future.

\footnotetext{
${ }^{1}$ Student of Master Program in Notary Program UNISSULA email noe kusuma@yahoo.co.id

2 Lecturer of Faculty of Law UNISSULA

${ }^{3}$ Wilbet D. Kolkman 2012 Hukum Tentang Orang Hukum Keluarga Dan Hukum Waris Di Belanda dan Indonesia Pustaka Larasan Denpasar page. 148

${ }^{4}$ Act Number 30 of 2004 concerning Notary Position (State Gazette of the Republic of Indonesia Number 117 of 2004. Addition to the State Gazette of the Republic of Indonesia Number 4432) Article 38
} 
In accordance with the provisions of Law Number 2 year 2014 on Notary Position, it states that: "The contents of the deed must not be changed or added, either in the form of overwriting, insertion, deletion, or deletion and replace it with another." Issuance of a deed without the Petitioner's knowledge indicates the existence of a criminal forgery letter, as stipulated in Article 263 paragraph (1) of the Criminal Code (KUHP), which reads: "Whoever makes a fake letter or falsifying a letter that can give rise to a right, engagement or debt relief, or which is intended to be evidence of something with a view to using or ordering another person to use the letter as if the contents were true and not false, threatened if the use could cause harm, because falsification of a letter, with a maximum imprisonment of six years. "Furthermore Article 264 paragraph (1) of the 1st Criminal Code states that:" falsification of a letter is threatened with a maximum imprisonment of eight years, if carried out on authentic deeds. "

When an inheritor leaves a will, a Notary needs to pay attention in making a will. In fact, there are times when the will cannot be fully implemented because there is legitime portie or whether there is a demand from the legitime portie.

Problem regarding the position of the will, one of them is the position of the will made by the Notary in the dispute between heirs, as happened from the case raised as a reference in this study, namely the Decision of the Blora Religious Court number 0427/Pdt.G/2014/PA.Bla.

In this case, the dispute between the heirs, makes the will as the basis of the Plaintiff to file a lawsuit and settle the dispute. It is a proof that a will deed can be a perfect proof of the distribution of inheritance rights which is the basis for decision in the case of the Religious Court Decision Number 0427/Pdt.G/2014/PA.Bla.

The problem formulations in this study are as follows: 1) How is the position of the will made by the Notary in the dispute between heirs? 2) What is the consideration and decision of the judge in the Decision of the Religious Court Number 0427/Pdt.G/2014/PA.Bla?

\section{Research Methods}

This research is descriptive analytical. Descriptive technique was used to describe the existence of a condition or position of legal or non-legal propositions. ${ }^{5}$ The type of research used was normative juridical, where an approach was taken to the problems that have been formulated by studying the statutory provisions relating to the issues discussed. This research used secondary data consisting of primary legal materials, secondary legal materials and tertiary legal materials. The legal materials provided information about legal materials and secondary legal materials, such as legal dictionaries, scientific journals, encyclopedias, material from the internet, magazines related to research material.

\section{Research Results And Discussion}

\subsection{Position of the Will Deed in the Dispute among Heirs}

Notaries who have a profession as public officials have the authority to make authentic evidence (Notarial deed). The Notary Deed made in the form of partij or relaas deed.

Likewise, the will certificate made by a Notary can be used as a perfect proof tool. So that if there is a dispute between the heirs, the will deed made by the inheritor (deceased) can clarify the position and part of each of the parties to the heirs.

Therefore a Notary must be responsible for the deed he made, the reasons are as follows: ${ }^{6}$

\footnotetext{
5 M. Iqbal Hasan 2002 Pokok-Pokok Materi Metode Penelitian dan Aplikasinya Cet I Gpageia Indonesia Jakarta page. 43

${ }^{6}$ G.H.S Lumban Tobing 1992 Peraturan Jabatan Notaris Erlangga Jakarta page. 325
} 
- Matters expressly determined by the Notary Position Regulation.

- If a deed does not fulfill the conditions regarding its form (gebrek in the vorm), is canceled in court, or is considered only valid as an underhand deed.

- In all cases, according to the provisions contained in Article 1365 concerning responsibility with elements of error (intentionality and negligence).

The Notary has the obligation to make sure what is contained in the Notary deed is truly understood and in accordance with the wishes of the parties, namely by reading it in front of the parties, so that it becomes clear and provides access to information including access to relevant laws and regulations for the parties signing of the Notary deed. The notary in carrying out his position plays an impartial and free role (impartiality and independence). ${ }^{7}$ The will deed should be made by a notary, it is called as Openbaar Testament. The will made by Notary is the most widely used and also the best, because the Notary can supervise the contents of the will, so he can give advice so that the contents of the testament do not conflict with the law. ${ }^{8}$

In western civil law (BW), it recognizes 3 (three) kinds of wills, namely:

- The General Testament is a will made by a notary, by means of the person who will leave the inheritance come to the Notary and declare his will and request the Notary to make a notary deed, this process must attended by two witnesses.

- Olographic Testament, is a will written entirely by hand and signed by the testator himself.

- Closed (confidential) testament, a will written by the testator himself or written by someone else who is told to write his final will. It must always be closed and sealed. In his submission to the Notary must be attended by four witnesses. 9

Testament has the meaning of the last message delivered by the deceased person (usually with regard to wealth and so on). The will creates a legal relationship between the inheritor and the recipient of the will. Based on the theory of legal certainty, the position of the will deed, case being discussed in this research, was a valid authentic deed. It was intended for the initial proof of the distribution of assets which were originally in the form of land used by the Plaintiff. The will deed's existence can clearly guarantee ownership of the object of dispute in this study. Based on Law Number 5 year 1960 concerning Basic Agrarian Principles in Article 19, it is stated that in order to create legal certainty in the land sector, the government implements a land registration program. The land that has been registered will be given a proof of land rights, as a strong evidence of land ownership. Regarding the transfer or delivery of land rights, there are two opinions, the first is that buying and selling process. It must be done with an authentic deed followed by land registration to obtain a certificate as proof of land rights. Authentic deed is drawn up by the Land Deed Officials, not only as evidence for registration but also an absolute requirement for a delivery agreement. This opinion was represented by Mariam Darus Badrulzaman and Saleh Adiwinata. Mariam Darus Badrulzaman argued that the registration agency, not only means to provide strong evidence, but also creates material rights. Material rights to a land object occur at the time of registration. In this connection, one important principle of land rights is the principle of publicity. The opinion adopted by Mariam Darus Badrulzaman above, seems to be strongly influenced by the teachings of causal theory, which considers that legal relations are obligatory, while levering is the result. This means that the new levering is valid, and therefore only makes those who

\footnotetext{
7 Herlin Budiono 2007 Kumpulan Tulisan Hukum Perdata di Bidang Kenotariatan Citra Aditya Bakti Bandung page. 22

${ }^{8}$ Subekti 2003 Pokok-Pokok Hukum Perdata Intermasa Jakarta page. 110

${ }^{9}$ Eman Suparman 2005 Hukum Waris Indonesia PT. Refika Aditama Bandung page. 98-100
} 
receive submission as owners.

Land disputes often occur due to ownership status. Problems will arise if the status of ownership later changes, either through buying and selling or inheritance or grants. Problems regarding land arise due to ignorance and indifference of the landowner to the status of the land he owns. The existence of a land certificate will have the legal power. Landowners will also not feel worried about the property (land) they have. It means that the owner does not register the land with the authorized institution, namely the Land Office or the National Land Agency. A land certification is very important regarding its legality before the law.

With the existence of a land certificate will make the land has legal power. Landowners will also not feel worried about the property (land) they have. Like other assets, land needs to get a legal recognition by the state. To realize the guarantee of legal certainty in the land sector, there are two things that must be considered, namely the need for written land law and the implementation of land registration. Simply stated, land registration activities have two objectives, including the provision of legal certainty and certainty of land rights. Regarding this matter, the implementation of land registration, there are two interests (parties) that are protected. First, the interest of the land rights holder is as manifestation of legal certainty, the land owner will receive proof of land registration in the form of a certificate. Second is the interest of other parties, namely prospective buyers and prospective creditors. This is intended to be able to easily obtain data that is believed to be true.

Authentic deed is as evidence that has perfect verification power. It can be used by parties and their heirs as well as all those who have the right from the inheritor regarding what is contained in the deed. Authentic Deed is a binding proof which means that the truth of the things written in the deed must be acknowledged by the judge, ie the deed is considered true as long as the truth is that no other party can prove otherwise. Whereas the object of the dispute in the form of a plot of land with a house above it is inheritance which ultimately requires legal certainty due to a legal event, namely the heir dies and makes a will that contains the division of each right from the heirs.

The lawsuit resulted in a peace letter of the sharing between the Plaintiff and the Defendant, the both parties accepted voluntarily the contents of the will made by the inheritor. They accepted the will was made in accordance with the provisions and did not ignore the rights of the beneficiary heirs. The position of the will is still a consideration point of the judge in making a decision.

The Testament Deed as an authentic deed submitted by the plaintiff in Blora District Court still had perfect proof power, because the inheritor had given each part of the Plaintiff and Defendant. This will deed became basis of islah bil ma'ruf done by Blora Religious Court. The inheritor wanted the distribution of his inheritances carried out peacefully.

\subsection{Decisions and Considerations of Judges in Verdict of the Religious Court Number 0427/Pdt.G/2014/PA.Bla}

The Decision of the Blora Religion Court number 0427/Pdt.G/2014/PA.Bla originated from Endang Suprapti binti Hadi Soeprapto (Plaintiff) who conducted underhand married Alm. Moelyono (Inheritor). Previously Moelyono when he was alive, was officially married with Mamiek Suparmi. The marriage did not have children, and then raised a child, namely Residia Agung Nugroho bin Sukoco Triwihartono (Defendant). During the marriage between the inheritor, the plaintiff purchased land and house which is located in Tambaksari Village, Blora Subdistrict, Blora Regency with a Certificate of Ownership Number 237/Tambaksari with a letter dated 11 December 2003 Number 283/Tambaksari/2003, Area 706 m2. The purchase was before Notary Niken Sukmawati , 
$\mathrm{SH}, \mathrm{M.Kn}$ with the Deed of Sale and Purchase Number 066/Bla/2010. This plot of land and the house was later become the object of the dispute. Upon the wishes of the Moelyono (inheritor), the name of the original owner in the certificate was change (previously the name used moelyono and Endang Suprapti) into Moelyono.

Furthermore, the disputed object, the late Moelyono made a will before the Notary Niken Sukmawati, S.H, M.Kn Number 26 dated October 19, 2012, the main contents are:

- The object of the dispute is divided into $1 / 3$ (one third) parts, namely for the deceased Moelyono, Plaintiff and Defendant.

- The object of the dispute must later be sold and the results will be divided into $1 / 3$ (one third) part after deducting the costs.

- The plaintiff is appointed as the executor of the will of the deceased Moelyono with all rights that according to law can be owned by the holder of the office.

- The right of the Plaintiff's part is entirely her property and cannot be contested by anyone.

- The rights of the part of the deceased Moelyono will be given to the Defendant.

When Moelyono passed away, the Plaintiff who originally occupied the house and land of the object of the dispute, was expelled by the Defendant and then the land object was controlled by the Defendant. Based on this event, the Plaintiff filed a lawsuit against the Defendant based on the will deed previously made by the late Moelyono and seized guarantee (Conservatoir Beslag) against the object of the dispute.

According to the panel of judges, the issue raised the dispute was the actions committed by the Defendant as an unlawful act or not. Unlawful act is an act committed by someone where the act in question is detrimental to another person but the act is not based on an agreement. Someone can be said commits an unlawful act must be fulfilled such conditions as an act, the act must be against the law, there is a loss, there is a causal relationship between acts against the law and losses and errors. Since the expansion of the notion of unlawful acts is not only violating the law, but also means violating the subjective rights of others, the legal obligations of the perpetrators, decency and propriety in society. Related to this, based on Standaard Arest year 1919, acting or not acting is an unlawful act if it is proven that the act violates the law and violates the subjective rights of others. It means violating a special authority given by law to each person. Jurisprudence provides an understanding of subjective rights including: Individual rights in the form of freedom, honor, good name, the right to property, in the form of material rights and other absolute rights. Violation of the subjective rights of others can be categorized as an illegal act if the act directly violates the subjective rights of others based on the present view requires a violation of behavior. According to written or unwritten laws that should not be violated by the perpetrator and there is no a justification for the law and contradicts the legal obligations of the perpetrator. Legal obligations are defined as legal obligations, both written and unwritten laws (including criminal acts of theft, embezzlement and destruction).

Contrary to a decency method, it is contrary to moral norms, as long as the norm is recognized as a legal norm in a society's life. Then it contradicts the principle of propriety in people's lives towards themselves and others. Related to this matter, it must be considered between their own interests and the interests of others by following propriety based on society's norms.

Consideration of the judge of the Blora Religious Court in deciding the case number 0427/Pdt.G/2014/PA.Bla was the existence of a Testament Deed made by the late Moelyono during his life. It was declared valid by the Panel of Judges, so that the Defendant or other person was authorized to surrender in cash $1 / 3$ (one third) of the value of the object of the dispute or auctioned and carried out profit sharing according to the 
Testament Deed Number 26 dated October 19, 2012 as mentioned in point 4.

Associated with the judge's decision in the case, the panel of judges gave advice to carry out a dispute with the issue of ma'ruf and there was an agreement through a peace letter to distribute the will of the late Moelyono. The peace was based on the will deed made by the late Moelyono before Notary Niken Sukmawati, SH, M.Kn with Number 26 dated October 19, 2012. Therefore, an agreement has been reached between the Plaintiff and the Defendant to end up civil case Number 427/Pdt/G/2014/PA.Bla peacefully.

The role of the Judge in this case was to punish the Parties for complying with the contents of the peace based on the Will Deed made by Notary Niken Sukmawati, S.H. M.Kn Number 26 dated October 19, 2012 and punished parties to pay court fees jointly and advised to hold Islah Bil Ma'ruf so as to create a peace agreement.

In addition, in making decisions based on the will, the amount of the will deed will not exceed $1 / 3$ of all assets.

\section{Clossing}

\subsection{Conclusion}

Based on the description above, it can be concluded:

- The will deed is an authentic deed made by a Notary in accordance with the rules and provisions which its existence can be used as a strong evidence in a legal act, especially relating to a dispute between heirs. This is because the making of a deed must fulfill three elements, namely outward, formal, material. If one of the three elements cannot be fulfilled, it can lead to a civil dispute that can arise later on.

- In that case, Islah (peace agreement) occurs or the parties made a peace letter based on the will deed made by the Notary. So that in this case the will is a valid authentic deed, so the judges used it in deciding the case in the dispute.

\subsection{Suggestion}

- Before making a deed, a Notary must carefully examine the documents that will be used as the basis for devising the deed, especially the truth of the data between the opponents. Deed made by a Notary is an authentic account which the truth must be accountable, so that in the event of a dispute related to the deed in this case the will, a Notary is only a deed maker and cannot be charged in the case of a dispute between heirs.

- In deciding on a case involving a dispute between heirs in the will, the judges consider that a Notary who has fulfilled the procedure in making an inheritance deed so that the judge's decision gives a fair judgment to the plaintiff.

\section{References}

[1] Eman Suparman 2005 Hukum Waris Indonesia PT. Refika Aditama Bandung

[2] G.H.S Lumban Tobing 1992 Peraturan Jabatan Notaris Erlangga Jakarta

[3] Habib Adjie 2009 Sanksi Perdata dan Administratif Terhadap Notaris Sebagai Pejabat Publik Cet 2 PT Refika Aditama Bandung

[4] Herlin Budiono 2007 Kumpulan Tulisan Hukum Perdata di Bidang Kenotariatan Citra Aditya Bakti Bandung

[5] M. Iqbal Hasan 2002 Pokok-Pokok Materi Metode Penelitian dan Aplikasinya Cet I Ghlmia Indonesia Jakarta

[6] Subekti 2003 Pokok-Pokok Hukum Perdata Intermasa Jakarta

[7] Wilbet D. Kolkman 2012 Hukum Tentang Orang Hukum Keluarga Dan Hukum Waris Di Belanda dan Indonesia Pustaka Larasan Denpasar

[8] Kitab Undang-Undang Hukum Perdata 


\section{JURNAL AKTA}

Position Of The Deed Of Will Made By...

Volume 5 Issue 2, June 2018

(Nurul Kusumawati)

[9] Undang-Undang Nomor 30 Tahun2004 Tentang Jabatan Notaris 